\title{
Organizational Learning and Impact on the Quality of Creative Performance
}

\author{
Ahmed Abdul Salam Ahmed Al-Salim, Shawqi Naji Jawad \\ University of Samarra \\ Amman Arab University/ Jordan
}

\begin{abstract}
This study was based on the descriptive analytical method, which represents a group of companies producing medicines in all of Iraq, The number of these companies until preparation of this study are 18 , The sample of the study was taken from these companies in a simple random sample method for 12 companies. The sampling unit consisted of the assistance of the general managers of the company and the heads of the departments. The number of them was 78 , one of the most important results which we found that there is a statistically significant effect of organizational learning on the quality of the creative performance of staff to general managers and heads department. Depending on the findings of the study we presented numbers of recommendations, the most important that all medicine manufacturers should adopt modern management concepts, practically the principle of organizational learning must become able to adapt and harmony with the environmental challenges. Additionally, To assist the heads of departments and provide them with information and sources of knowledge to achieve creative performance.
\end{abstract}

Keywords: Organizational learning, creative performance, institutions producing medicine.

\section{Introduction}

It the contemporary business environment of new concepts in the field of organizations, was emerged sometimes the concept of organizational learning was the most prominent modern management concepts that emerged from a series of economic and humanitarian considerations and requirements. In recent years there has been a growing interest in organizational learning as an urgent strategic necessity for the progress and survival of organizations. It contributes decisively to change and environmental uncertainty creates opportunities for sustainable competitive advantage and makes the organization look like a unit with a common vision in exploiting different branches of knowledge (Yusuf, 2015).

The Learning transcends the simple model of learning based on the acquisition of information and skills, which stands at cloning and the limits of memory, into a deep learning style based on the influence of knowledge for constantly changing behavior. It should be emphasized that there is a hierarchy of learning that begins with learning from classical, which begins with increasing one's knowledge, then recalling and reproducing, then using facts and procedures to reach the individual's understanding as a result of deep learning (Li, et. al, 2014).

The quality of creative performance under the leadership of organizations motivates workers to change and innovation in the methods of work and services. Therefore, the practice of creative performance by the management of companies producing Iraqi medicine is a requirement for those companies that are looking for excellence in providing the best. The concept of quality of creative performance has become a concept associated with organizational learning in organizations in general and in medicine production companies in particular. Through the foregoing, the organizational learning must be reflected positively on the business results, 
making this learning an effective tool for improving the quality of creative performance. Therefore, organizations must make dynamic changes in the organization to ensure the continuity of organizational learning which contributes to the survival and sustainability (Mumford, et. al, 2017).

Derive the practical significance of this study of the necessity for organizational learning to improve creative performance in the medicine industry, as a preliminary step stimulating institutions producing Iraqi medicine This study is contemplating to take advantage of the results of the study that developed perceptions of support for the application of organizational learning and its impact on the quality of creative tool for assistants general managers and heads department In the institutions producing the Iraqi medicine.

\section{Theoretical Studies}

Organizational Learning: Is one of the important topics that has attracted the attention of business organizations in our world today, as it represents diagnosis and detection of weaknesses and shortcomings in their performance in order to meet the rapid environmental challenges facing organizations, finding solutions to problems and selecting suitable alternatives (Saadi, 2006). (Kostas \& John 2006,p.80) defined learning as the process of acquiring knowledge and using information that enables the organization and its members to adapt to the ever-changing environment. (Thomas \& Allen 2006, p.124) the process that leads to learning the organization continuously. The organization does not learn on its own but learns through what its members learn through experience, training, and interaction with others, enabling them to acquire new skills in concentration, induction, analysis, and construction of theoretical and scientific frameworks (Langer, 2017).

A number of studies have contributed to enhancing the current study orientation on the impact of organizational learning on the quality of creative performance, including ( Almagali, 2009) "The availability of organizational learning and its impact on creative behavior practices": A field study of the views of employees in Jordanian public lending institutions". Pointed study (Khandekar \& Sharma, 2005) "Organizational Learning in Indian Organizations".

Acquisition of Knowledge: The organization's ability to extract information and ideas from the external and internal environment and from its visions through the recruitment of individuals who have knowledge from outside sources or through experiments carried out inside and outside the organization (Pivec \& Potocan, 2015). And contributed to the study (Khandekar \& Sharma, 2005) in enhancing the dimensions of the current study, including the acquisition of knowledge.

Learning Work Skills: Is the process of learning to acquire the skills needful to improve the performance of employees through training and rehabilitation courses that create creativity and innovation and critical thinking to develop those skills (Eraut, et. al, 2000). (Farago \& Skyrme ,1995) suggest that the process of learning new business skills is to learn the skills needed to adapt to the new environment variables that will have an impact on the success of the organization.

Learning to Adapt: Is to teach the working personnel the necessary skills to accomplish the work and work procedures that lead to the gradual development and in accordance with the current requirements of the organization, which in turn ensure survival and continuity for itself. Therefore, learning to adapt focuses on the ability of workers to harmonize and adapt to the current conditions of the environment surrounding the organization (Obeidi,2009).

Awareness: Is the attention of individuals to the selection of appropriate stimuli from the environment surrounding the work. Because the individual often draws his attention directly to the new and unusual stimuli, the situation in which the individual is aware of what is happening around him at the present time, (Bear, 2003). Pointed (Zhu, et. al, 2017) Awareness as dealing more sensitively with the environment, opening 
up to good information, and adding awareness to multiple perspectives.

Social Learning: Is a type of organizational learning, which is solicitude about the almost permanent change in the behavior of individuals. It occurs in a social context through the social interactive attitudes experienced by individuals, which reflect on the individual knowledge, values, experiences, and skills, through which it can interact positively with its social environment and achieve its goals and objectives (Eren, et. al, 2015).

\section{Quality of creative performance:}

Quality: The concept of quality can be expressed as a degree of brilliance and excellence in performance by optimal exploitation the time and effort in performing business without mistakes during work to avoid repetition of work (Çelik \& Kitapçi, 2014).

Creative performance: The creative performance is a major challenge facing managers at the twenty-first century through the use of the Possibilities and staff capabilities, which in turn will promote innovation and acceleration of the Organizational process (Beheshtifar, 2013). Managers should recognize that sustainability and the challenge of competition are conditional on the generation of creative ideas and innovative products through a process called the creative process (Wu, et. al, 2016). Creative performance is, therefore, the cornerstone of innovations that make organizations more Pioneer in the business environment and more distinct ( $\mathrm{Lu}$, et. al, 2016: 20).The study (Yeh \& Huan, 2017) was" Assessing the impact of work environment factors on employee creative performance of fine-dining restaurants". While the study (Gupta \& Singh, 2015) talk a bought "Leadership and Creative Performance behaviors in R \& D Laboratories Examining the Mediating Role of Justice Perceptions". The impact in reinforcement current study orientation is a tool to keep pace with development and differentiation, which generates the need to identify the creative performance in our organizations, Including the Organization in question.

New Idea Generation: It can be expressed in the generation of ideas. It's the ability to generate alternatives that an innovator should characterize (Youssef, 2015). Many people tend to confine their minds to one alternative, which in turn deprives them of many positives that may be in other thought alternatives (Girotra, et. al, 2010). While the study (Mumford, 2000), that individuals are the source of any new idea when generated. While the (Kleysen \& Street, 2001) to generate ideas, but what is the process of owning new ideas that came from blending or re-organize information and ideas to solve current problems or improve performance and give an idea generator recipe excellence and creativity.

Problems Solving: The problem is a new and unfamiliar situation to which the individual is exposed. The solution is to process of limitation and understanding the problem and collecting data by using all previous experiences and information stored in memory and finding appropriate solutions to the problem (Yusuf, 2015). Pointed (Zayat, 2003), that problem-solving is just a mental activity in which the interaction of cognitive representation of previous experiences with the current position of the components of the problem in order to find that solution.

Exploration Opportunity: Is the process of seeking and applying creative opportunities for the purpose of learning and benefiting from them (Yusuf, 2015) And (Kleysen \& Street, 2001), explore the opportunities that the process is one of the most basic conditions for the start of the process of transition from old systems rooted in the organization to modern systems that will push the organization towards excellence.

\section{Research Problem}

In the business environment, which is characterized by continuous change and extreme competitiveness. medicine companies direction a real challenge to multi-tasking and activities that require a focus on organizational learning in order 
to master the performance of the employees and achieve the quality of creative performance, which attracts the researcher's attention to the necessity to study the subject of organizational learning and its impact on the quality of performance Creative.

Some of the studies also noted the existence of obstacles to organizational learning that affect the creative performance, including (Askar \& Rajab,2016), (Obeida,2016) , (Hon, et. al, 2014) and (Tsai, et. al, 2015), where it became clear from during previous studies. The absence of successful organizational learning elements as well as a poor-quality creative performance of employees in those organizations.

\section{Determinants}

We should look for any troubles and difficulties and challenges facing the researcher during the period of preparation of research, and this research can be summarized as follows:

1) The lack of seriousness of some sample dealing with the researcher, where some of them refuse to answer the questionnaire.

2) The aversion of the researcher to add the category of general managers in the Iraqi medicine industry and therefore the lack of time for them to answer the questionnaire, which prompted the researcher to exclude the category of managers.

3) Nonconformity between theoretical concepts about the dimensions of organizational learning and what is Practically applicable in the Iraqi medicine companies to some of the Deputy Managers General and heads of departments.

\section{Hypotheses}

Ho. No effect is statistically significant at $(\alpha=$ 0.05 ) to learn organizational dimensions (acquire knowledge, learn work skills, learning to adapt, Awareness, social learning) on the quality of creative performance dimensions (New Idea Generation, Problems Solving, Exploration Opportunity) in institutions Search?.

H1. The effect is statistically significant at $(\alpha=$ 0.05 ) to learn organizational dimensions (acquire knowledge, learn work skills, learning to adapt, Awareness, social learning) on the quality of creative performance dimensions (New Idea Generation, Problems Solving, Exploration Opportunity) in institutions Search?.

\section{Conceptual Model}

Figure 1: Study Model

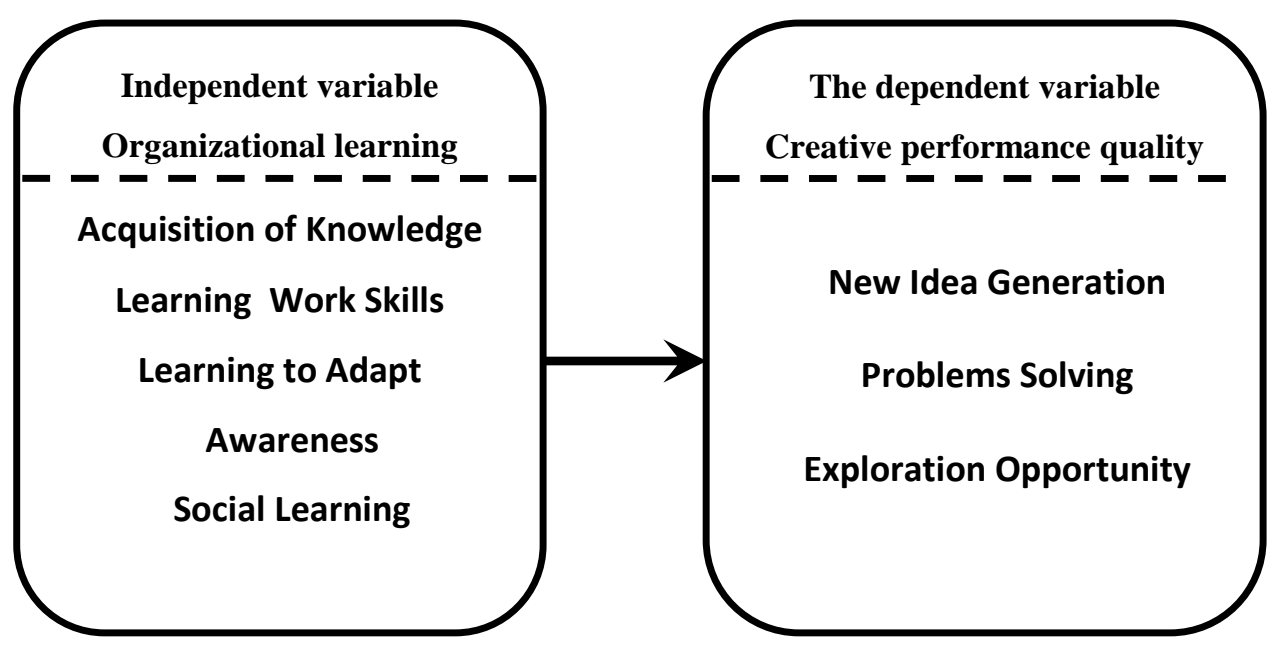




\section{Methodology}

The current research follows the descriptive and analytical statistical methodologies for examining and evaluating variables and hypotheses.

\section{Population and Sampling Unit}

The study community is a private and public company operating in the medicine sector in Iraq, Which became by (18) certified company until the preparation of the study, a simple random sample method for (12) companies were characterized by multiple production lines where, The sampling unit assistants general managers and heads department, and this became the study sample size of (102) individuals were the questionnaire distributed the recover (85) questionnaire was (78) questionnaire valid for statistical analysis at a rate of recovery of $(76.4 \%)$.

\section{Source of Information}

The source of information consists of two main categories:

The primary source of information is based on a structured questionnaire developed by the researchers to cover all research variables. For the questionnaire distribution and collection, soft copies using surveymonkey.com, have been used to facilitate both processes in order to reach the highest number of respondents.

The secondary sources of information, which are based mainly on previous sources, include dissertations, theses, researchers, books, and websites.

\section{Limits}

The study limits were as follows:

1) Place Boundary: The study will be limited to public and private companies producing medicines in Iraq.

2) Time Boundary: The study was completed during the first quarter of 2018.

3) Human Resources Boundary: The study limited the views of the general manager assistant and heads of departments only (102).

4) Scientific Boundary: investigate the relationship between the dimensions of the independent variable are organizational learning (knowledge acquisition, work skills learning, adaptive learning, vigilance, and social learning), and dimensions of the dependent variable, the quality of creative performance (new generation, problem-solving, and opportunity discovery).

\section{Statistical Methods}

The analysis process was conducted using Statistical Package for Social Science Software (SPSS) including, measures of central tendency, measures of dispersion, multiple regression analysis, Cronbach's' alpha, VIF test, and Kolmogorov-Smirnov test.

\section{Procedure}

The study Check the apparent truth of the questionnaire content by presenting it to (7) arbitrators of the faculty members with specialization from Iraqi universities (University of Baghdad, Al-Nahrain University, Mustansiriya University and Kufa University). As it was arbitrated by professors from outside Iraq where the questionnaire was sent with a copy of the research plan by e-mail for the purposes of arbitration, Some of the vocabulary judged by the arbitrators have been excluded, some of which have been rephrased in accordance with the culture of the respondents.

\section{Conclusions}

\section{Below are the main characteristics and findings of this research:}

In terms of gender distribution, The results showed that the percentage of male respondents was $72 \%$, while the females were $28 \%$. This is evidence that most of the general manager assistant and heads of departments in Iraqi companies producing the medicine are male. Also the majority of the sample in terms Age groups showed that the percentage of the highest in this 
study was in the category 34-41, where they accounted for 49, while the age group 42-49 was $25 \%$, and the age group 50 and above was $15 \%$, and the age group 26-33It was $11 \%$.

Educational Qualifications the highest percentage of respondents was bachelor's degree holders $75 \%$. In addition, they were the most prevalent group in the study sample. Most of them were heads department, followed by $17 \%$ of the holders of the master's degree and $8 \%$ of the Ph.D. holders. By talking about the Years of Experience; The results showed that $41 \%$ of the sample had a 5-10 years' experience, followed by $32 \%$ of those with 11-16 years' experience, while $18 \%$ of the sample had less than 5 years of experience. $9 \%$.

Table (1): The average and standard deviations of all dimensions of organizational learning and quality of creative performance

\begin{tabular}{|c|l|c|c|c|}
\hline $\begin{array}{c}\text { No. } \\
\text { Dimension }\end{array}$ & Dimension & $\begin{array}{c}\text { Arithmetic } \\
\text { average }\end{array}$ & $\begin{array}{c}\text { Standard } \\
\text { Deviations }\end{array}$ & $\begin{array}{c}\text { Degree of } \\
\text { approval }\end{array}$ \\
\hline 1. & Acquisition of Knowledge & 4.29 & 0.31 & High \\
\hline 2. & Learning Work Skills & 4.00 & 0.38 & High \\
\hline 3. & Learning to adaptation & 4.17 & 0.26 & High \\
\hline 4. & Awareness & 3.97 & 0.44 & High \\
\hline 5. & Social Learning & 4.37 & 0.30 & High \\
\hline 6. & New Idea Generation & 4.03 & 0.39 & High \\
\hline 7. & Problems Solving & 4.18 & 0.34 & High \\
\hline 8. & Exploration Opportunity & 4.08 & 0.31 & \\
\hline
\end{tabular}

The results in Table (1) showed that the sample trends are positive towards the knowledge acquisition. The general arithmetic average for knowledge was 4.29 and the standard deviation was 0.31 . It was found that after the key factor in the quality of creative performance due they acquire the knowledge they need to do their jobs on their own. While the sample trends are positive towards the mentioned paragraphs after learning the work skills because the general arithmetic mean was 4.0 and the standard deviation was 0.38 . This explains the response of the sample of the study that learning the skills of the work supports the quality of creative performance in the institutions producing Iraqi medicine through the development of work skills for the assistance of general managers and heads of departments. also, the general arithmetic mean was 4.17 and the standard deviation was 0.26 . This explains that the answers of the sample of the study which show that after learning to adapt supports the quality of creative performance and high degree due to the attention of the assistants of general managers in the Iraqi institutions producing medicine training and development. As well as the general arithmetic average was 3.97 and a standard deviation of 0.44 . This explains that the responses of the sample of the study with high results indicating that Awareness has a significant role in organizational learning and that the medicine producing establishments Iraqi urged assistants of general managers and heads of departments to use new thinking strategies and diverse knowledge to meet the challenges surrounding them.

However that the general arithmetic average was 4.37 and a standard deviation of (0.30). This explains that the responses of the sample of the study high results indicating that after the social learning creates the soul of cooperation by working as an integrated team in the institutions producing the Iraqi medicine. While the general arithmetic means for the generation of new ideas was (4.03) and a standard deviation of (0.39). This explains the generation of new ideas was high and according to the results of the study which confirmed that the Iraqi medicine companies encourage workers to deal with the new ideas. Achieves the quality of their creative performance. also The arithmetic average of the year was (4.18) and a standard deviation was (0.34), and this explains that the solution of the problems documented a high degree from the view of study sample, that institutions producing the Iraqi medicine have employees have the 
ability to devise solutions Appropriate to the problems facing their institutions. however the general arithmetic average Dimension discovering the opportunities was (4.08) and the standard deviation was (0.31), which explains the ability of the assistance of the general managers and heads of departments to discover the opportunities through analyzing the external environment which enables them to discover Creative and noncreative opportunities in addition to the experience of others to achieve the quality of creative performance in the institutions producing Iraqi medicine.

\section{Below is the discussion of the research's hypotheses:}

Table (2): Analysis of variance test to determine the impact of the organizational dimensions of learning on the quality of creative performance

\begin{tabular}{|c|c|c|c|c|c|c|c|}
\hline Source of Variance & $\begin{array}{c}\text { Sum of } \\
\text { Squares }\end{array}$ & DF & $\begin{array}{c}\text { Mean } \\
\text { Square }\end{array}$ & $\begin{array}{c}\mathbf{F} \\
\text { Calculated }\end{array}$ & Sig & $\begin{array}{c}\text { R } \\
\text { Square }\end{array}$ & $\begin{array}{c}\text { Adjusted } \\
\text { R2 }\end{array}$ \\
\hline Between Groups & 12.417 & 5 & 2.483 & \multirow[t]{3}{*}{43.561} & \multirow[t]{3}{*}{0.00} & \multirow[t]{3}{*}{0.866} & \multirow[t]{3}{*}{0.751} \\
\hline Within Groups & 4.127 & 72 & 0.057 & & & & \\
\hline Total & 16.544 & 77 & & & & & \\
\hline
\end{tabular}

Based on the results of the statistical analysis, hypothesis H0 was rejected, and the H1 hypothesis was accepted. Therefore, there is a statistically significant relationship $(\alpha=0.05)$ between organizational learning and the quality of creative performance, Table (2) shows the impact of organizational learning on its dimensions (Acquisition of Knowledge, Learning Work Skills, Learning to adaptation, Awareness, and Social Learning) on the quality of creative performance in its dimensions (New Idea Generation, problems solving and Exploration Opportunity), The results of statistical analysis of organizational learning on the quality of creative performance (0.000), which is less than the level of significance (0.05) statistical significance. As well as the total (F) calculated (43.561) While the (F) table (2.289) at the degrees of freedom $(5,72)$ Thus, the calculated $(\mathrm{F})$ is greater than the table $(\mathrm{F})$. The correlation coefficient $(\mathrm{R})(0.866)$ was at the significance level $(\alpha=0.05)$. The coefficient of determination (R2) was (0.751).

Where the results of this study generally correspond with previous studies that have been found, such as the study Al-Majali (2009), AlObeidi (2009), Sweetman et.al (2011) and Yeh \& Huan (2017). Because all confirm the existence of a relationship or the effect of organizational learning and behavior or creative performance.
1) Look at the large number of global variables has become necessary to the institutions producing Iraqi medicine, To face those challenges, internal and external, and in line with those challenges, Which necessitates these institutions adopt modern administrative concepts, especially with regard to organizational learning, so that they are able to adapt and harmony with the surrounding environment.

2) Provide information and sources of knowledge sufficient to the assistance of general managers and heads of departments in the institutions producing Iraqi medicine, which enables them to achieve creative performance.

3) On the institutions producing Iraqi medicine, Create departments that specialize in organizational learning management within their organizational structure, So as to increase the awareness of its employees, to spread and activate the culture of organizational learning to raise awareness among employees, Which leads ultimately to increase their creativity.

4) Must be working institutions producing Iraqi medicine, To increase the capacity assistants of the general managers and Heads of Departments to deal with environmental conditions surrounding

\section{Recommendations:}


them, Exploiting opportunities, overcoming threats and responding to changes, and achieving the quality of creative performance.

5) To support the Awareness available to the assistance of the general managers and heads of departments in the Iraqi medicine producing institutions and to work to strengthen them and develop them through the preparation of programs that develop such Awareness better.

6) Work on the establishment of sections within the organizational structure of the institution specialized in organizational learning, So as to increase the awareness of its employees, And activate the culture of organizational learning to raise awareness among employees, Which ultimately leads to increased creative performance.

7) Availability of opportunities In front of the assistance of general managers and heads of departments in the institutions producing Iraqi medicine, And give them a bigger role in solving the problems facing their work by taking the proposals they make Information and analysis and then take the appropriate decision, which will lead to a solution to those problems.

8) Need to put Institutions producing medicine Iraqi simplified procedures enabling employees From discovering opportunities for achieving creative performance and increasing knowledge For the assistance of the general managers and heads of departments in those institutions.

9) It calls for the researcher to Procedure future different studies So as to learn and evaluate the commitment of other sectors The dimensions of organizational learning and its impact on the quality of creative performance.
This research was supported/partially supported by (University of Samarra). We thank our colleagues from our university who provided insight and expertise that greatly assisted the research, although they may not agree with all of the results in the paper. We would like to thank Mr. Baraa Mohammed Al-Hilali for his support and his experience to finish this paper. The special thanks to Mr. Marwan Ahmed Yousef for completing the structure of the paper.

\section{Declaration of Conflicting Interests}

The authors declared no potential conflicts of interest with respect to the research, authorship, and/or publication of this article.

\section{References:}

[1] Abdul H, M. R. (2010).Adaptive ELearning Tool Based on VR. Project Report, Faculty of Computing and Information Technology, KAU, Saudi Arabia.

[2] Al-magali, A. Y. (2009). The availability of organizational learning and its impact on creative behavior practices: A field study of the views of workers in Jordanian public lending institutions. Journal of Administrative Studies, 36 (1), 53-77.

[3] Al-Obeidi, A.A. (2009). Organizational Learning Tools and Their Role in Adopting Innovative Marketing Skills: An Exploratory Study of the Opinions of a Sample of Directors of the General Company of Southern Cement Companies. Al Ghari Journal of Administrative and Economic Sciences, 2(13), 151-182.

[4] Askar, S. S., \& Rajab, S. I. (2016). Role of creative performance skills in assessing job performance A survey of the views of a sample of nurses working in Azadi Teaching Hospital in the city of Kirkuk. Journal of Kirkuk University for Administrative and Economic Sciences, 6 (2).

[5] Baer, R. A. (2003). Mindfulness Training as a Clinical Intervention: A Conceptual and Empirical Review. Journal Clinical 
Psychology Science and Practice, 10 (2), 125-143.

[6] Beheshtifar, M. (2013). Employee Creativity: A compulsory Factor in Organizations. Interdisciplinary Journal of Contemporary Research in Business, 5(2), 242-248.

[7] Bingham, C. B., \& Kahl, S. (2014). Anticipatory learning. Strategic Entrepreneurship Journal, 8(2), 101-127.

[8] Chenhall, E. C., \& Chermack, T. J. (2010). Models, definitions, and outcome variables of action learning: A synthesis with implications for HRD. Journal of European Industrial Training, 34(7), 588608.

[9] Davidovich, G. L., Gennadyevich, S. D., \& Viktorovich, K. M. (2016). University technology platform for anticipatory learning. Journal of Economy of the region, 12(1).

[10] Eraut, M., Alderton, J., Cole, G., \& Senker, P. (2000). Development of knowledge and skills at work. Journal of Differing visions of a learning society, 1. 231-262.

[11] Eren, M. I., Buchanan, B., \& O'Brien, M. J. (2015). Social learning and technological evolution during the Clovis colonization of the New World. Journal of Human Evolution, 80. 159-170.

[12] Farago, J., \& Skyrme, D.J. (1995).Learning Organization. Retrieved from http://www.skyrme.com/insights/3lrnorg.

[13] Garavan, T. N., \& McCarthy, A. (2008). Collective learning processes and human resource development. Journal of Advances in developing human resources, 10(4), 451-471.

[14] Girotra, K., Terwiesch, C., \& Ulrich, K. T. (2010). Idea generation and the quality of the best idea. Journal of Management Science, 56(4), 591-605.

[15] Gupta, V., \& Singh, S. (2015). Leadership and Creative Performance Behaviors in R\&D Laboratories: Examining the
Mediating Role of Justice Perceptions. Journal of Leadership \& Organizational Studies, 22(1), 21-36.

[16] Hon, A. H., Bloom, M., \& Crant, J. M. (2014). Overcoming resistance to change and enhancing creative performance. Journal of Management, 40(3), 919-941.

[17] Khandekar, A., \& Sharma, A. (2005).Organizational Learning in Indian Organizations: a Strategic HRM Perspective. Journal of Small Business and Enterprise Development. 12 ( 2), 211226.

[18] Kitapçi, H., \& Çelik, V. (2014). The relationship between ambidexterity, organizational learning capacity, and firm quality performance: An empirical study. Journal of Procedia-Social and Behavioral Sciences, 109. 827-836.

[19] Kleysen,R.F., \& Street,C.T.(2001).Toward a Multi-Dimensional Measure of Individual Innovative Behavior. $c$ Intellectual Capital, 2 (3), 284-296.

[20] Langer, A. M. (2017). Information Technology and Organizational Learning: Managing Behavioral Change in the Digital Age. CRC Press.

[21] Li, Y., Chen, H., Liu, Y., \& Peng, M. W. (2014). Managerial ties, organizational learning, and opportunity capture: A social capital perspective. Asia Pacific Journal of Management, 31(1), 271-291.

[22] Loon Hoe, S. (2011). Action learning: reflections of a first-time coach. Development and Learning in Organizations: An International Journal, 25(3), 12-14.

[23] Lu, V. N., Capezio, A., Restubog, S. L. D., Garcia, P. J. M., \& Wang, L. (2016). In pursuit of service excellence: Investigating the role of psychological contracts and organizational identification of frontline hotel employees. Journal of Tourism Management, 56. 8-19.

[24] Mumford, M. D., Steele, L., Mulhearn, T., McIntosh, T., \& Watts, L. L. (2017). 
Leader Planning Skills and Creative Performance: Integrating Past, Present, and Future. Handbook of Research on Leadership and Creativity, 17.

[25] Mumford, M. (2000).Managing Creative People: Strategies and Tactics for Innovation. Journal of Human Resources Management Review, 10 (3).313-351.

[26] Obaidah, S.M. (2016). The Relationship between Organizational Climate and Creative Behavior An Empirical Study on Teaching Staff in Middle Faculties of Community in the Gaza Strip, MA unpublished Faculty of Commerce. Department of Business Administration, Islamic University, Gaza, Palestine.

[27] Pivec, N., \& Potocan, V. (2015). The influence of employees' values on the acquisition of knowledge in organizations. Nase gospodarstvo/Our economy, 61(6), 19-27.

[28] Saadi, M. Y. N, .(2006). Organizational Learning and Organizational Memory and its Impact on Human Resources Management Strategies. unpublished doctoral dissertation, Baghdad University, Faculty of Management and Economics, Baghdad, Iraq.

[29] Tsai, C. Y., Horng, J. S., Liu, C. H., \& Hu, D. C. (2015). Work environment and atmosphere: The role of organizational support in the creativity performance of tourism and hospitality organizations. International Journal of Hospitality Management, 46. 26-35.

[30] Wu, Y., Chang, K., \& Sha, X. (2016). Computers in Human Behavior Creative performance in the workplace: The roles of Simmelian ties and communication media. Journal Homepage, 63.575-583.

[31] Yeh, S. S., \& Huan, T. C. (2017). Assessing the impact of work environment factors on employee creative performance of fine-dining restaurants. Journal of Tourism Management, 58. 119-131.

[32] Yusef, M. A. (2015). The Impact of Organizational Learning on Creative
Behavior of Department Heads in Private Hospitals in Amman. Unpublished Master Thesis, Amman Arab University, Amman, Jordan.

[33] Zayat, F. M. (2003). Cognitive Psychology. Publishing House for Universities Egypt.

[34] Zhu, Q., Qu, Y., Geng, Y., \& Fujita, T. (2017). A comparison of regulatory awareness and green supply chain management practices among Chinese and Japanese manufacturers. Journal of Business Strategy and the Environment, 26(1), 18-30.

\section{About the authors:}

Ahmed Abdul Salam Ahmed Al-Salim is an academic researcher in the research of $\mathrm{Ph} . \mathrm{D}$. seeking a doctorate in the Department of Business Administration Specialization: Human Resources Management Studied at Amman Arab University Amman / Jordan. Participation in academic seminars. Director of the Quality and Performance Assessment Department of the Faculty of Archeology at present. In addition to the presidency of the Department of Quality and Academic Accreditation of the University of Samarra at present / iraq.

Professor Shawqi Naji Jawad is an academic researcher in the Department of Business Administration Specialization: Human Resources Management at Amman Arab University Amman / Jordan. Participation in academic seminars. 